\title{
Disease Development and Changes in the Natural Pseudomonas syringae pv. tomato Populations on Field Tomato Plants
}

\author{
D. A. Cuppels, Southern Crop Protection and Food Research Centre, Agriculture and Agri-Food Canada, 1391 \\ Sandford Street, London, Ontario N5V 4T3, Canada; and J. Elmhirst, Abbotsford Agricultural Centre, 1767 Angus \\ Campbell Road, Abbotsford, British Columbia V3G 2M3, Canada
}

\begin{abstract}
Cuppels, D. A., and Elmhirst, J. 1999. Disease development and changes in the natural Pseudomonas syringae pv. tomato populations on field tomato plants. Plant Dis. 83:759-764.

The probe TPRI, derived from the Pseudomonas syringae pv. tomato gene cluster controlling production of the phytotoxin coronatine, was used in conjunction with the semiselective medium VBTar to trace natural populations of the pathogen on tomato plants from just before planting to harvest. In a survey of transplant seedlings in greenhouses, $P$. syringae pv. tomato populations ranged from $8 \times 10^{0}$ to $3.2 \times 10^{5} \mathrm{CFU} / \mathrm{g}$ of leaf tissue. Copper-sprayed seedlings had similar populations to nonsprayed plants, but copper tolerance was common among the $P$. syringae pv. tomato strains surveyed. Transplant seedlings from three greenhouses were tagged, randomly planted in three grower fields, and monitored for $P$. syringae pv. tomato and disease severity over two growing seasons. Statistical analysis indicated that, when the $P$. syringae pv. tomato populations of greenhouse plants were small, as recorded in this study, there was no correlation between greenhouse infestation and disease severity in the field. Environmental conditions played a greater role than greenhouse infestation in disease development. Once formed, leaf lesions remained a good inoculum source $\left(10^{4}\right.$ to $\left.10^{5} \mathrm{CFU}\right)$ throughout the 7-week life of the leaf. Bacterial speck damage correlated well in both years $(r=0.80$ and $r=0.86$, respectively) with $P$. syringae pv. tomato population levels.
\end{abstract}

Bacterial speck, caused by Pseudomonas syringae pv. tomato, is one of the most persistent bacterial disease problems found in the tomato-growing regions of North America (12). Not only can the pathogen decrease the yield of the tomato plant through foliar necrosis, but it also can blemish the fruit so that it cannot be sold on the fresh market or peeled effectively by whole-pack processors. In Ontario, field tomatoes are started from greenhousegrown transplant seedlings sown in closely spaced 288-unit plug trays; one greenhouse may contain over a million plants. $P$. syringae pv. tomato can survive as an epiphyte on greenhouse-grown tomato plants for extended periods of time (25). Disseminated primarily by water, it has the potential to move through plug greenhouses very quickly; thus, infested seedlings could become an important inoculum source for field epiphytotics. Transplants infested with bacterial speck may go undetected because of lack of visible symptoms or because of difficulties in distinguishing bacterial speck lesions from those of other diseases (12).

Corresponding author: D. A. Cuppels

E-mail: cuppelsd@em.agr.ca

Accepted for publication 5 May 1999.

Publication no. D-1999-0526-01R

(C) 1999 For the Department of Agriculture and Agri-Food, Government of Canada, Minister of Public Works and Government Services Canada
Once the seedlings are planted in the tomato fields, where they are exposed to a larger number of disease-causing agents, diagnosis becomes even more difficult.

Several ecological and epidemiological studies of the bacterial speck pathogen have been performed since the first serious outbreak of the disease in the late 1970s (1,4,5,13,19,23-25). Epiphytic P. syringae pv. tomato populations on leaf surfaces provide an important inoculum source (13). Until recently, the only means of monitoring these populations was to plate samples on a differential or semiselective medium, such as King's B medium (17), and then to test individual fluorescent colonies for pathogenicity (23). Our lab has developed a rapid procedure for quantifying this pathogen which employs the semiselective medium VBTar and a diagnostic DNA probe (TPR1) (8). VBTar has $\mathrm{D}(-)$ tartrate as the sole carbon source, and TPR 1 is a $P$. syringae pv. tomato sequence derived from the gene cluster controlling production of the phytotoxin coronatine (21). The only microorganism detected with the TPRIVBTar procedure is $P$. syringae pv. tomato. In a previous study, all $244 P$. syringae pv. tomato strains isolated from Ontario tomato fields produced coronatine (8). The TPRI-VBTar procedure is quite effective at detecting extremely low numbers of the bacterial speck pathogen on plant material.

One of the intents of the present study was to modify this procedure into one that could be used to screen large numbers of samples from symptomless plants for $P$. syringae pv. tomato populations. We used this procedure to determine the level of bacterial speck infestation of transplant seedlings from several commercial greenhouses, to follow natural $P$. syringae pv. tomato populations on transplant seedlings from just before planting to harvest, and to monitor the $P$. syringae pv. tomato populations in aging lesions on inoculated field tomato plants. We also evaluated whether the population level found on field plants correlates with the severity of bacterial speck-like symptoms and whether the population levels on transplant seedlings can be used to predict the disease severity on mature plants later in the season.

\section{MATERIALS AND METHODS}

Field study design. In late March of 1991 and 1992, tomato (Lycopersicon esculentum Mill.) cv. 9230 seeds were sown in three commercial transplant seedling greenhouses (A, B, and C) in tagged 288well trays containing Pro-mix (eight trays per greenhouse in 1991 and nine trays per greenhouse in 1992). When the seedlings were approximately 6 weeks old, just before they were transplanted to the field, leaf samples were collected from each tray. For each tray, the leaf sample came from 20 randomly chosen plants. The $P$. syringae pv. tomato population (CFU/g fresh weight of leaf tissue) for each tray was determined using the semiselective medium VBTar and the DNA diagnostic probe TPR1 (procedure below).

The tagged trays were randomly distributed to each of three fields (1, 2, and 3) and planted in a completely randomized design by the growers using their own transplanting equipment. The tray distribution was as follows: field 1 (1991) had trays B1, A8, B2, A7, A4, A6, C3, C1 (two trays per row); field 2 (1991) had trays C6, C5, B3, A2, B4, A1, B7, B5 (two trays per row); field 3 (1991) had trays A3, C4, C8, B6, B8, C7, A5, C2 (two trays per row); field 1 (1992) had trays C8, A9, C1, B2, C4, B9, A1, B6, A6 (three trays per row); field 2 (1992) had trays A8, C9, C3, B1, A5, B7, C6, B3, A2 (three trays per row); field 3 (1992) had trays A4, C2, A3, C7, B8, C5, A7, B4, B5 (three trays per row). The tomato fields were located within a $60-\mathrm{km}$ radius of each other in southwestern Ontario. TOM-CAST disease severity values (DSV) ranging from 1 to 4 , which 
are a function of leaf wetness and mean air temperature and indicate the potential threat to tomatoes from early blight, Septoria leaf spot, and anthracnose (11), were recorded for each site throughout the two growing seasons. The only field to receive a bactericide spray was field 1; it was sprayed once in early June 1991 with cupric hydroxide (Kocide 101; $2.25 \mathrm{~kg} / \mathrm{ha}$ ).

At selected times throughout the growing season, a symptomless leaf sample was collected from 30 randomly selected plants (one leaflet from each plant) representing each tagged tray. These samples were transported to the laboratory on ice and assayed for $P$. syringae pv. tomato populations using the procedure described below. Although population determinations based on bulked samples tend to overestimate the actual population size (15), this method was chosen because of its speed and simplicity when dealing with a large number of samples. At the time of collection, disease incidence on these same plants was estimated using a variation of the procedure described by Bonn (4). In this procedure, counts of bacterial speck-like lesions were performed on three leaflets (approximately $50 \mathrm{~cm}^{2}$ in total area), originating from the second or third fully exfrom each of 30 randomly selected plants (representing each tagged tray). Disease incidence was expressed as lesions per 30plant leaf sample. At each sampling time, several bacterial speck-like lesions were collected and tested for the presence of $P$. syringae pv. tomato; purified isolates from each lesion were tested for pathogenicity as described previously (7). On the last sampling date, 100 fruit were randomly collected from plants representing each tray, and the number of bacterial specklike lesions per sample was determined.

Quantitation of $P$. syringae pv. tomato on symptomless leaves. Tomato leaf samples were collected from the greenhouses panded leaf below the plant growing tip,

or tomato fields and kept on ice until they could be processed the following day. Approximately $10 \mathrm{~g}( \pm 0.1 \mathrm{~g})$ of leaf tissue was placed in $100 \mathrm{ml}$ of sterile distilled water and shaken $(150 \mathrm{rpm})$ for $30 \mathrm{~min}$ at $22^{\circ} \mathrm{C}$. The wash water was passed through a glass fiber filter (Whatman GF/A, $9 \mathrm{~cm}$ ) to remove plant material. The filtrate then was centrifuged at 7,500 rpm for $15 \mathrm{~min}$ to collect the leaf surface bacteria. The pellet, which usually is not visible, was suspended in $5 \mathrm{ml}$ of sterile distilled water, and the resulting suspension was serially diluted in sterile distilled water. Aliquots $(0.1 \mathrm{ml})$ of each dilution were spread on VBTar agar (Vogel-Bonner minimal medium in which the citrate has been replaced with $0.3 \%$ $\mathrm{D}(-)$ tartrate as the sole carbon source). After 3 days incubation at $25^{\circ} \mathrm{C}$, colony lifts were prepared of selected VBTar plates as previously described (8).

The TPRI DNA fragment was random prime labeled with digoxigenin (DIG)-11dUTP (Roche Molecular Biochemicals, Laval, Quebec) as instructed by the manufacturer. Colony lifts were hybridized to the DIG-labeled TPR1 probe using a variation of the procedure described by Sambrook et al. (22). The lifts were washed in $3 \times$ SSC $(0.15 \mathrm{M}$ sodium chloride plus $0.015 \mathrm{M}$ sodium citrate, $\mathrm{pH}$ $7.0) / 0.1 \%$ sodium dodecyl sulfate (SDS) at $50^{\circ} \mathrm{C}$ for $1 \mathrm{~h}$ before being incubated at $42^{\circ} \mathrm{C}$ for $90 \mathrm{~min}$ in hybridization buffer (HB) containing $5 \times$ SSC, $50 \%$ formamide, $0.1 \% \mathrm{~N}$-lauroyl-sacrosine, $0.02 \% \mathrm{SDS}$, and $5 \%$ blocking reagent (Roche) $(5$ lifts $/ 55 \mathrm{ml}$ in one bag). The lifts then were gently rubbed with a Kimwipe moistened with the hybridization buffer to remove bacterial cellular debris. The lifts were placed in a new bag with fresh $\mathrm{HB}$ containing 10 to 15 $\mathrm{ng} / \mathrm{ml}$ of denatured DIG-labeled TPR 1 probe and incubated at $42^{\circ} \mathrm{C}$ for $6 \mathrm{~h}$. The filters were washed twice in $2 \times \mathrm{SSC} / 0.1 \%$ $\operatorname{SDS}(5 \mathrm{~min} / \mathrm{wash})$ at room temperature and then twice in $0.1 \times \mathrm{SSC} / 0.1 \% \mathrm{SDS}$ at

Table 1. Copper sensitivity of selected Pseudomonas syringae pv. tomato strains

\begin{tabular}{|c|c|c|c|}
\hline Strain & Geographic origin & Isolation year & Copper sensitivity \\
\hline NCPPB $1008^{b}$ & U.S. & 1942 & $\mathrm{~S}$ \\
\hline DC3000 & England & 1960 & $\mathrm{~S}$ \\
\hline CNPB1323 ${ }^{b}$ & France & 1971 & $\mathrm{~S}$ \\
\hline ICMP3357 & New Zealand & 1972 & $\mathrm{~S}$ \\
\hline 487 & Greece & 1979 & $\mathrm{~T}$ \\
\hline DCT6D1 & Ontario-Tilbury & 1981 & $\mathrm{~T}$ \\
\hline 208B (Race 1) & Ontario-Wallaceburg & 1982 & $\mathrm{~T}$ \\
\hline JL1035 & U.S.-California & 1983 & $\mathrm{~T}$ \\
\hline DC894H & Ontario-Harrow & 1989 & $\mathrm{~T}$ \\
\hline DC92-1 & Ontario-Leamington & 1992 & $\mathrm{~T}$ \\
\hline DC96-1 & Ontario-Niagara & 1996 & $\mathrm{~T}$ \\
\hline DC97-2 & Ontario-Niagara & 1997 & $\mathrm{R}$ \\
\hline DC98-1 & Ontario-London & 1998 & $\mathrm{~T}$ \\
\hline
\end{tabular}

${ }^{a}$ Bacterial strains that could not grow on mannitol-glutamate-yeast extract (MGY) plates containing copper concentrations of $0.8 \mathrm{mM}$ or higher were considered copper-sensitive; copper-tolerant strains grew on MGY plates with copper concentrations of $1.0 \mathrm{mM}$ or less; copper-resistant strains could withstand concentrations of 1.2 to $2.0 \mathrm{mM}$ (6).

${ }^{b}$ NCPPB, National Culture Collection of Plant Pathogenic Bacteria, Hertfordshire, England; CNPB, Collection Nationale Bactéries Phytopathogènes, Angers, France; ICMP, International Collection of Microorganisms from Plants, Auckland, New Zealand. $68^{\circ} \mathrm{C}$. Colonies on the lifts that hybridized to the DIG-labeled probe were detected by the Genius system (Roche) and the chemiluminescent substrate Lumi-Phos 530 (Roche). Luminescent colonies were detected by exposing the lift to X-ray film (Kodak X-Omat AR) for 5 to $20 \mathrm{~min}$.

Effect of lesion age on the $P$. syringae pv. tomato population of field tomato plant lesions. Sixty 4-week-old greenhouse-grown tomato seedlings (cv. Bonny Best) were planted $46 \mathrm{~cm}$ apart in a plot on the Southern Crop Protection and Food Research Centre farm in London, Ontario. The plants were spray-inoculated 1 week later with a water suspension of $P$. syringae pv. tomato strain DCT6D1 $\left(1.6 \times 10^{9}\right.$ $\mathrm{CFU} / \mathrm{ml}$ ). Seven days after inoculation, a map was prepared showing the location of bacterial speck lesions on the infected leaves. At 8, 14, 21, 28, 35, 42, and 49 days after inoculation, six randomly selected mapped lesions were excised from the plants. Each lesion, cut in quarters, was incubated at $4^{\circ} \mathrm{C}$ in $1 \mathrm{ml}$ of potassium phosphate buffer containing $0.1 \%$ Difcopeptone (KPP) for $30 \mathrm{~min}$. The suspension was serially diluted in KPP, and aliquots of each dilution were spread on VBTar agar and King's B medium. After 3 days incubation at $25^{\circ} \mathrm{C}$, colony lifts of selected VBTar plates were prepared and processed as described above.

Determination of copper sensitivity. The $P$. syringae pv. tomato strains listed in Table 1 were tested for copper sensitivity on mannitol-glutamate-yeast extract (MGY) medium (2) supplemented with $\mathrm{CuSO}_{4} \cdot 5 \mathrm{H}_{2} \mathrm{O}$ at the following concentrations: $0.5 \mathrm{mM}, 0.8 \mathrm{mM}, 1.0 \mathrm{mM}, 1.2 \mathrm{mM}$, $1.5 \mathrm{mM}$, and $2.0 \mathrm{mM}$. Bacteria from 48-hold cultures grown at $25^{\circ} \mathrm{C}$ on nutrient broth-yeast extract (NBY) (26) agar were suspended in sterile distilled water to a density of approximately $10^{6} \mathrm{CFU} / \mathrm{ml}$. A $10-\mu 1$ droplet of this suspension was spotted in duplicate onto MGY plates supplemented with the various copper concentrations and onto MGY plates containing no copper. The assay was performed two or three times for each strain. The minimal inhibitory concentration (MIC) was the concentration that inhibited confluent growth after a 72-h incubation period at $25^{\circ} \mathrm{C}$. Bacterial strains that could not grow on plates containing copper concentrations of $0.8 \mathrm{mM}$ or higher were considered copper-sensitive; copper-tolerant strains grew on plates with copper concentrations of 1.0 $\mathrm{mM}$ or less; copper-resistant strains could withstand concentrations above $1.0 \mathrm{mM}(2)$.

Statistical methods. All statistical calculations were performed with SAS (version 6.04) (SAS Institute, Cary, NC). Correlation analysis was done on log-transformed estimates of bacterial populations ( $\log _{10} \mathrm{CFU} / \mathrm{g}$ fresh weight of plant tissue) and lesion numbers $\left(\log _{10}\right.$ lesions per 50 $\mathrm{cm}^{2}$ fresh weight of leaf tissue or $\log _{10}$ lesions per 100-fruit sample). 


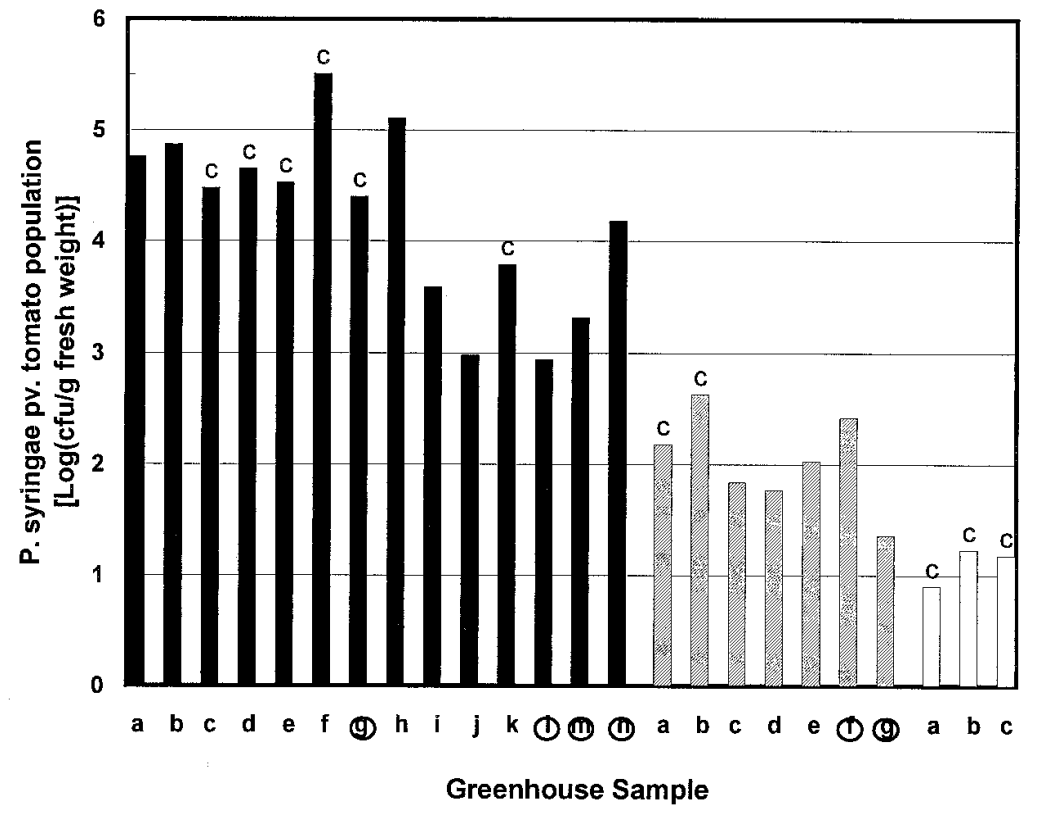

Fig. 1. Pseudomonas syringae pv. tomato populations of greenhouse-grown tomato transplant seedlings. In 1990 (solid bars), six greenhouses (GH) and 13 tomato cultivars were sampled: GH1, a (cv. 7983) and b (cv. 722); GH2, c (cv. 722), d (cv. 9230), e (cv. 7814), f (cv. 8812), and g (cv. Mountain Pride); GH3, h (cv. 7122), i (cv. N701), and j (cv. Ohio 8245); GH4, k (cv. 9478); GH5, 1 (cv. Red Star); GH6, m (cv. Sunrise) and n (cv. VeePick). In 1991 (light colored bars), seven greenhouses and three cultivars were sampled: GH1, a (cv. TH318); GH2, b (cv. 9230); GH3, c (cv. 9230); GH4, d (cv. 9230); GH5, e (cv. 9230); GH6, f (cv. Sunrise); GH7, g (cv. Sunrise). In 1992 (open bars), three greenhouses and one cultivar (cv. 9230) were sampled: GH1, a; GH2, b; GH3, c. A "c" at the top of a bar indicates a cultivar that has been sprayed with a bactericide (copper oxychloride at $2.6 \mathrm{~kg} / 1,000$ liters) within 14 days of sampling date. Letters representing fresh market cultivars have been circled.

\section{RESULTS AND DISCUSSION}

Presence of $P$. syringae pv. tomato in transplant seedling greenhouses. Over the 3-year sampling period, the P. syringae pv. tomato populations of healthy tomato plants randomly selected from transplant seedling greenhouses ranged from $3.2 \times 10^{5} \mathrm{CFU} / \mathrm{g}$ fresh weight of tissue (sample1990-f) to $8 \times 10^{0} \mathrm{CFU} / \mathrm{g}$ fresh weight of tissue (sample 1992-a), with no bacterial speck symptoms being observed on any of the plants in these greenhouses (Fig. 1). The 13 cultivars (four fresh market and nine processing) sampled in 1990 supported a noticeably larger population than the three cultivars sampled in 1991 and 1992. Samples 1990-d, 1991-c, and 1992-a came from the same greenhouse and cultivar (H9230), and the $P$. syringae pv. tomato numbers were $4.5 \times 10^{4}, 1.3 \times 10^{2}$, and $8.0 \times 10^{0} \mathrm{CFU} / \mathrm{g}$ fresh weight of leaf tissue, respectively. Plants that had been sprayed with copper-based bactericides did not necessarily have lower $P$. syringae pv. tomato numbers than plants that had not been sprayed. In a random sampling of $P$. syringae pv. tomato strains from our culture collection (Table 1), we found that all strains isolated since the late 1970 s, when the first serious outbreaks of bacterial speck occurred (12), were
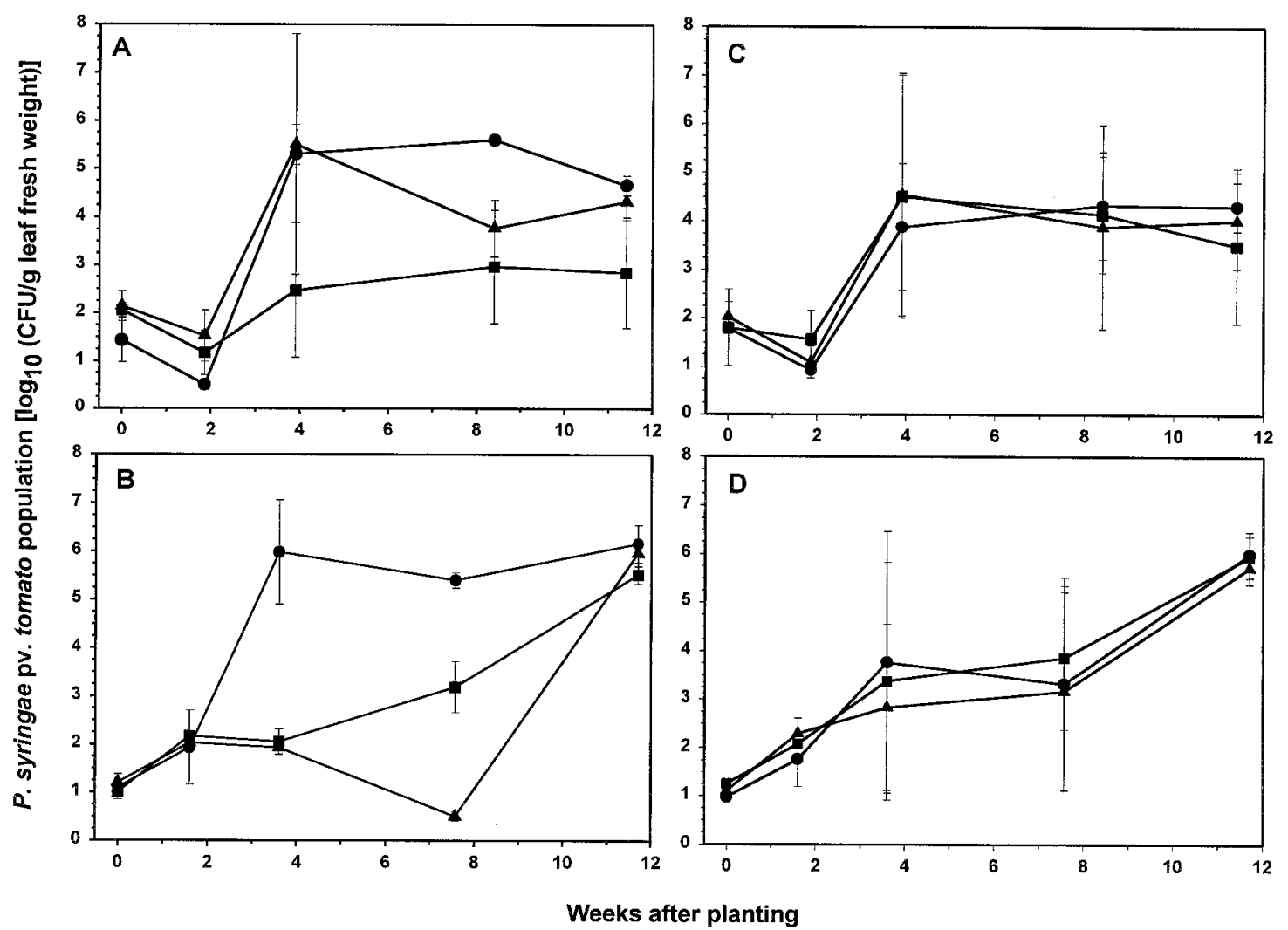

Fig. 2. Seasonal progression of Pseudomonas syringae pv. tomato populations on transplant seedlings originating from three different greenhouses planted in three different fields in southwestern Ontario during 1991 (A and C) and 1992 (B and D). Each field received seedlings from each greenhouse. The results were expressed as the mean $\log _{10} \mathrm{CFU} / \mathrm{g}$ fresh weight of symptomless leaf tissue for plants derived from each field (A and $\left.\mathbf{B}\right)$ and from each greenhouse (C and D). For $\mathbf{A}$ and $\mathbf{B}$ : field 1, $\bullet$; field 2, $\mathbf{\square}$; field 3, $\mathbf{\Delta}$. For $\mathbf{C}$ and $\mathbf{D}$ : greenhouse A, $\mathbf{\bullet}$; greenhouse B, $\mathbf{\square}$; greenhouse C, $\mathbf{\Delta}$. 
Table 2. Pseudomonas syringae pv. tomato populations and disease severity on 1991 field tomato plants from transplant seedling greenhouses $\mathrm{A}, \mathrm{B}$, and $\mathrm{C}^{\mathrm{a}}$

\begin{tabular}{|c|c|c|c|c|c|c|}
\hline \multirow{2}{*}{$\begin{array}{l}\text { Field and } \\
\text { sampling date }\end{array}$} & \multicolumn{3}{|c|}{$\begin{array}{c}\log _{10}(\mathrm{CFU} / \mathrm{g} \text { fresh weight } \\
\text { of leaf tissue })^{\mathrm{b}}\end{array}$} & \multicolumn{3}{|c|}{ Disease severity of seedlings ${ }^{c}$} \\
\hline & GH-A & GH-B & GH-C & GH-A & GH-B & GH-C \\
\hline \multicolumn{7}{|l|}{ Field 1} \\
\hline 6 May & 1.70 & $<1$ & 1.70 & $\ldots$ & $\ldots$ & $\ldots$ \\
\hline 23 May $(13)^{d}$ & $<1$ & $<1$ & $<1$ & 0 & $<1$ & $<1$ \\
\hline 6 June (27) & 2.45 & 5.99 & 6.47 & $<1$ & 386 & 336 \\
\hline 8 July (59) & 5.60 & 5.53 & 5.72 & 87 & 199 & 182 \\
\hline 29 July (80) & 4.88 & 4.62 & 4.48 & $284(6.5)^{\mathrm{e}}$ & $531(59)$ & $230(48)$ \\
\hline \multicolumn{7}{|l|}{ Field 2} \\
\hline 6 May & 1.90 & 2.20 & 2.08 & $\ldots$ & $\ldots$ & $\ldots$ \\
\hline 23 May (13) & $<1$ & 1.70 & $>1$ & 0 & 0 & 0 \\
\hline 6 June (27) & 4.08 & 1.60 & 1.72 & $<1$ & $<1$ & 0 \\
\hline 8 July (59) & 3.60 & 3.70 & 1.60 & 0 & 1.3 & 7 \\
\hline 29 July (80) & 4.0 & 1.70 & 2.86 & $3(0)$ & $3(<1)$ & $7.5(<1)$ \\
\hline \multicolumn{7}{|l|}{ Field 3} \\
\hline 6 May & 1.78 & 2.32 & 2.32 & $\ldots$ & $\ldots$ & $\ldots$ \\
\hline 23 May (13) & 1.00 & 2.08 & 1.48 & 1.5 & $<1$ & 0 \\
\hline 6 June (27) & 5.11 & 5.94 & 5.45 & 24 & 42 & 35 \\
\hline 8 July (59) & 3.78 & 3.18 & 4.36 & 14 & 29 & 23 \\
\hline 29 July (80) & 4.04 & 4.18 & 4.73 & $96(22)$ & $428(38)$ & 289 (49) \\
\hline
\end{tabular}

a In late March, tomato seeds (cv. 9230) were sown in 288-unit plug trays in three transplant seedling greenhouses (GH-A, GH-B, and GH-C). On 6 May, eight seedling trays from each greenhouse were tagged, and plants were sampled for bacterial speck. The following week, seedlings were randomly planted in each of three southwestern Ontario fields.

b Throughout the season, 30-leaflet samples showing no symptoms of bacterial speck were randomly collected from plants originating from each of the trays and screened for $P$. syringae pv. tomato with the TPR1 DNA probe. Each number, expressed as $\log _{10}$ CFU/g fresh weight of leaf tissue, represents the mean for the trays from each greenhouse planted in each field.

c Number of bacterial speck-like lesions on three leaflets (approximately $50 \mathrm{~cm}^{2}$ in total area) close to growing point of plant was determined for each of 30 randomly selected plants from each greenhouse tray. Each number, expressed as lesions per 30-plant leaflet sample (approximately 1,500 $\mathrm{cm}^{2}$ ), is the mean for the trays (from each greenhouse) planted in each field.

${ }^{d}$ Number in parentheses is number of days after planting.

e On the last sampling date, 100 fruit were randomly selected from plants representing each tray and screened for bacterial speck-like lesions. Each number, expressed as lesions per 100-fruit sample, is the mean for the trays (from each greenhouse) planted in each field.

tolerant to copper. Thus, the reduction in $P$. syrin-gae pv. tomato populations seen in Ontario greenhouses between 1990 and 1992 may have been due to other factors, such as improved sanitation or cleaner seed.

$P$. syringae pv. tomato populations in processing tomato fields during 1991 and 1992. Although greenhouse-grown seedlings from both years had very low $P$. syringae $\mathrm{pv}$. tomato populations and were disease-free when first transplanted to the field, there were marked differences in the leaf surface population levels of the three fields as the season progressed (Fig. 2 and Tables 2 and 3). P. syringae pv. tomato populations were more affected by planting site than by greenhouse origin. There was a significant relationship between $\log _{10} P$. syringae pv. tomato $\mathrm{CFU} / \mathrm{g}$ fresh weight of leaf tissue and $\log _{10}$ bacterial speck-like lesions per 30-plant leaf sample (Pearson correlation coefficients, calculated from all readings except day 0 , were 0.796 for 1991 and 0.856 for 1992 , with $P=0.0001$ for both). In both years, speck-like lesions were collected throughout the growing season and tested for the presence of $P$. syringae pv. tomato; 53 of 55 lesions in 1991 and 67 of 78 lesions in 1992 were confirmed as bacterial speck. Thus, there is a strong likelihood that the bacterial speck-like lesions observed on these plants were caused by $P$. syringae pv. tomato and not by some other tomato pathogen or a physiological condition.

In neither year did the $P$. syringae pv. tomato populations of the seedlings at planting time predict the disease severity seen on leaves or fruit at the end of the season (Pearson correlation coefficients for 1991 were $0.043[P=0.842]$ and $0.026[P$ $=0.905]$, respectively, and for 1992, 0.473 $[P=0.013]$ and $0.084[P=0.678]$, respectively). The $P$. syringae pv. tomato epiphytic population on plants with a disease severity rating of 10 or less never exceeded $10^{4} \mathrm{CFU} / \mathrm{g}$. Lindemann et al. (20) found a significant correlation between the largest $P$. syringae pv. syringae population and the severity of brown spot of bean at harvest time. They concluded that $10^{4} \mathrm{CFU} / \mathrm{g}$ of leaflet may represent an infection threshold population for this pathogen. Jardine and Stephens (16) used $10^{5} \mathrm{CFU} / \mathrm{g}$ fresh weight of tissue as the threshold for bacterial speck infection in developing a predictive system for timing bactericide applications.

However, infection thresholds most likely do not remain constant and may be affected by environmental conditions and the physiological state of the host plant.

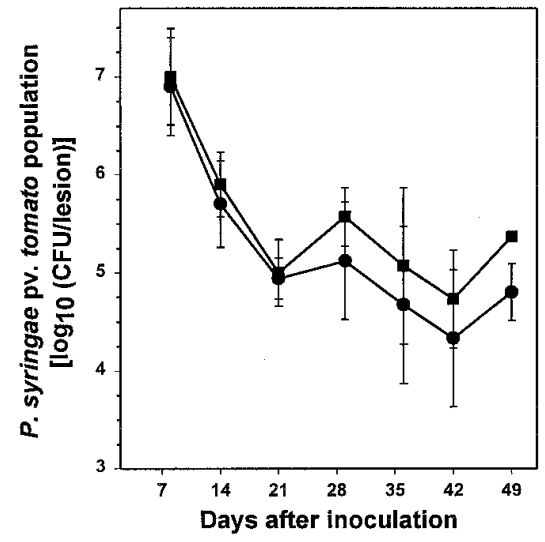

Fig. 3. Effect of lesion age on the Pseudomonas syringae pv. tomato population of field tomato leaf lesions. One week after 5-week-old tomato plants (cv. Bonny Best) were spray-inoculated with $P$. syringae pv. tomato DCT6D1, the location of fully developed lesions was mapped on tagged leaves. The TPR1 probe was used to monitor the $P$. syringae pv. tomato population size (-) of selected lesions over a 7-week period. The total bacterial population size ( $\boldsymbol{\square})$ also was determined.

Field 2 remained almost disease-free throughout the 1991 season, with a mean $P$. syringae pv. tomato population that did not exceed $1 \times 10^{4} \mathrm{CFU} / \mathrm{g}$ fresh weight of leaf tissue. By 3.5 weeks, the $P$. syringae pv. tomato population of fields 1 and 3 had increased to more than $1 \times 10^{5} \mathrm{CFU} / \mathrm{g}$. Although the population in field 1 remained high until the end of the sampling period, the population in field 3, which had the same TOM-CAST DSVs as field 1, was a $\log$ factor lower at 8 weeks. By the end of the sampling period, just before harvest, the $P$. syringae pv. tomato populations and disease incidence for these two fields were equivalent. Between 6 July and 29 July, fields 1 and 3 had received three rains, while field 2 had just one. In 1992, between 12 and 18 July, leaf wetness and DSVs (3 to 4) were high for all three fields. By 4 August, all fields had large $P$. syringae pv. tomato populations $\left(2.4 \times 10^{5}\right.$ to $2.7 \times 10^{6} \mathrm{CFU} / \mathrm{g}$ of leaf tissue) and widespread disease. Thus, elevated moisture levels may have been a significant contributing factor in the high disease severity ratings observed just before harvest in both years. Field studies of the snap bean pathogen $P$. syringae pv. syringae have shown a strong association between intense rains and large increases in the bacterial population of leaf surfaces (14).

Despite the large number of leaf lesions found on the last sampling date in both years, the number of lesions per 100-fruit sample was low, particularly in 1991, and may reflect environmental conditions occurring during early fruit development $(<3$ $\mathrm{cm}$ in diameter), which is the only time that fruit are susceptible to infection (10). 
Table 3. Pseudomonas syringae pv. tomato populations and disease severity on 1992 field tomato plants from transplant seedling greenhouses $\mathrm{A}, \mathrm{B}$, and $\mathrm{C}^{\mathrm{a}}$

\begin{tabular}{|c|c|c|c|c|c|c|}
\hline \multirow{2}{*}{$\begin{array}{l}\text { Field and } \\
\text { sampling date }\end{array}$} & \multicolumn{3}{|c|}{$\begin{array}{c}\log _{10}(\mathrm{CFU} / \mathrm{g} \text { fresh weight } \\
\text { of leaf tissue })^{\mathrm{b}}\end{array}$} & \multicolumn{3}{|c|}{ Disease severity of seedlings ${ }^{c}$} \\
\hline & GH-A & GH-B & GH-C & GH-A & GH-B & GH-C \\
\hline \multicolumn{7}{|l|}{ Field 1} \\
\hline 5 May & 1.00 & 1.30 & 1.00 & $\ldots$ & $\ldots$ & $\ldots$ \\
\hline 25 May $(11)^{d}$ & 1.11 & 2.04 & 2.64 & 8.3 & 5.3 & 13 \\
\hline 8 June $(25)$ & 6.93 & 6.20 & 4.81 & 27 & 58 & 36 \\
\hline 6 July (53) & 5.26 & 5.57 & 5.36 & 338 & 1,052 & 167 \\
\hline 4 Aug. (82) & 6.34 & 6.43 & 5.72 & $461(182)^{\mathrm{e}}$ & $612(260)$ & $531(333)$ \\
\hline \multicolumn{7}{|l|}{ Field 2} \\
\hline 5 May & $<1$ & 1.15 & 1.00 & $\ldots$ & $\ldots$ & $\ldots$ \\
\hline 25 May (11) & 2.18 & 2.11 & 2.23 & 6.3 & 9.7 & 8.3 \\
\hline 8 June (25) & 2.36 & 1.90 & 1.90 & $<1$ & $<1$ & 0 \\
\hline 6 July (53) & 3.80 & 2.96 & 2.83 & 13 & 4.7 & 6 \\
\hline 4 Aug. (82) & 5.46 & 5.73 & 5.38 & $636(434)$ & $581(459)$ & $579(444)$ \\
\hline \multicolumn{7}{|l|}{ Field 3} \\
\hline 5 May & 1.00 & 1.30 & 1.30 & $\ldots$ & $\ldots$ & $\ldots$ \\
\hline 25 May (11) & 2.00 & 2.08 & 2.00 & 0 & 1.7 & $<1$ \\
\hline 8 June (25) & 2.00 & 2.00 & 1.78 & 0 & 0 & 0 \\
\hline 6 July (53) & $<1$ & 3.04 & 1.30 & 0 & $<1$ & 0 \\
\hline 4 Aug. (82) & 6.18 & 5.66 & 6.03 & $1,078(201)$ & 993 (209) & $1,019(232)$ \\
\hline
\end{tabular}

a In late March, tomato seeds (cv. 9230) were sown in 288-unit plug trays in three transplant seedling greenhouses (GH-A, GH-B, and GH-C). On 5 May, nine seedling trays from each greenhouse were tagged, and plants were sampled for bacterial speck. The following week, seedlings were randomly planted in each of three southwestern Ontario fields.

b Throughout the season, 30-leaflet samples showing no symptoms of bacterial speck were randomly collected from plants originating from each of the trays and screened for $P$. syringae pv. tomato with the TPR1 DNA probe. Each number, expressed as $\log _{10}$ CFU/g fresh weight of leaf tissue, represents the mean for the trays from each greenhouse planted in each field.

c Number of bacterial speck-like lesions on three leaflets (approximately $50 \mathrm{~cm}^{2}$ in total area) close to growing point of plant was determined for each of 30 randomly selected plants from each greenhouse tray. Each number, expressed as lesions per 30-plant leaflet sample (approximately 1,500 $\mathrm{cm}^{2}$ ), is the mean for the trays (from each greenhouse) planted in each field.

${ }^{\mathrm{d}}$ Number in parentheses is number of days after planting.

e On the last sampling date, 100 fruit were randomly selected from plants representing each tray and screened for bacterial speck-like lesions. Each number, expressed as lesions per 100-fruit sample, is the mean for the trays (from each greenhouse) planted in each field.

Because all the greenhouse transplant seedlings assayed harbored a small but persistent $P$. syringae pv. tomato population, a potential inoculum source for bacterial speck was present in all the fields with environmental conditions determining the extent of $P$. syringae pv. tomato multiplication and lesion formation.

Effect of lesion age on the $P$. syringae pv. tomato population of field tomato plant lesions. Recently formed lesions (8 days after inoculation) averaged $10^{7} \mathrm{CFU}$ per lesion, but then the numbers rapidly dropped to approximately $10^{5} \mathrm{CFU}$ per lesion by 3 weeks (Fig. 3). At 4 weeks, non- $P$. syringae pv. tomato bacteria had begun to establish themselves in the lesions, but $P$. syringae pv. tomato still predominated. Like other members of the $P$. syringae species, $P$. syringae pv. tomato appears to be a good competitor on leaf surfaces (18). At 7 weeks, when the leaves were starting to show signs of senescence, lesions still contained a sizable population of the pathogen. The population in 3- to 7week-old lesions, averaging $10^{5} \mathrm{CFU} / \mathrm{g}$, may represent an equilibrium between resource availability and resource use within the lesion (3).

Because of their high specificity and the recent development of more rapid DNA hybridization assay formats (9), diagnostic DNA probes are gaining wide acceptance and are proving to be viable alternatives to immunological and cultural methods for disease diagnosis and field ecology studies. The probe-based techniques and approaches developed in this study should be helpful in the development of DNA probebased assays for other bacteria on other field crops.

\section{ACKNOWLEDGMENTS}

We thank Teresa Ainsworth for her able technical assistance and the Ontario Vegetable Growers' Marketing Board for their financial support.

\section{LITERATURE CITED}

1. Bashan, Y. 1985. Field dispersal of Pseudomonas syringae pv. tomato, Xanthomonas campestris pv. vesicatoria, and Alternaria macrospora by animals, people, birds, insects, mites, agricultural tools, aircraft, soil particles, and water sources. Can. J. Bot. 64:276-281.

2. Bender, C. L., and Cooksey, D. A. 1986. Indigenous plasmids in Pseudomonas syringae pv. tomato: Conjugative transfer and role in copper resistance. J. Bacteriol. 165:534-541.

3. Blakeman, J. P. 1991. Foliar bacterial pathogens: Epiphytic growth and interactions on leaves. J. Appl. Bacteriol. 70:49S-59S.

4. Bonn, W. G. 1980. Incidence and severity of bacterial speck of tomato in southwestern
Ontario in 1979. Plant Dis. 64:586-587.

5. Bonn, W. G., Gitaitis, R. D., and MacNeill, B. H. 1985. Epiphytic survival of Pseudomonas syringae pv. tomato on tomato transplants shipped from Georgia. Plant Dis. 69:58-60.

6. Cooksey, D. A. 1990. Genetics of bactericide resistance in plant pathogenic bacteria. Annu. Rev. Phytopathol. 28:201-219.

7. Cuppels, D. 1986. Generation and characterization of Tn5 insertion mutations in Pseudomonas syringae pv. tomato. Appl. Environ. Microbiol. 51:323-327.

8. Cuppels, D. A., Moore, R. A., and Morris, V. L. 1990. Construction and use of a nonradioactive DNA hybridization probe for detection of Pseudomonas syringae pv. tomato on tomato plants. Appl. Environ. Microbiol. 56:1743-1749.

9. DeBoer, S., Cuppels, D. A., and Gitaitis, R. D. 1996. Detecting latent bacterial infections. Pages 27-57 in: S. DeBoer, J. Andrews, and I. C. Tommerup, eds. Advances in Botanical Research. Vol. 23. Academic Press, London.

10. Getz, S., Stephens, C. T., and Fulbright, D. W. 1983. Influence of developmental stage on susceptibility of tomato fruit to Pseudomonas syringae pv. tomato. Phytopathology 73:3638 .

11. Gleason, M. L., MacNab, A. A., Pitblado, R. E., Ricker, M. D., East, D. A., and Latin, R. X. 1995. Disease-warning systems for processing tomatoes in eastern North America: Are we there yet? Plant Dis. 79:113121.

12. Goode, M. J., and Sasser, M. 1980. Prevention - the key to controlling bacterial spot and bacterial speck of tomato. Plant Dis. 64:831834.

13. Henis, Y., and Bashan, Y. 1986. Epiphytic survival of bacterial leaf pathogens. Pages 252-268 in: Microbiology of the phyllosphere. Cambridge University, Cambridge, Eng.

14. Hirano, S. S., Baker, L. S., and Upper, C. D. 1996. Raindrop momentum triggers growth of leaf-associated populations of Pseudomonas syringae on field-grown snap bean plants. Appl. Environ. Microbiol. 62:25602566.

15. Hirano, S. S., Nordheim, E. V., Arny, D. C., and Upper, C. D. 1982. Lognormal distribution of epiphytic bacterial populations on leaf surfaces. Appl. Environ. Microbiol. 44:695700 .

16. Jardine, D. J., and Stephens, C. T. 1987. A predictive system for timing chemical applications to control Pseudomonas syringae pv. tomato, causal agent of bacterial speck. Phytopathology 77:823-827.

17. King, E. O., Ward, M. K., and Raney D. E. 1954. Two simple media for the demonstration of pyocyanin and fluorescein. J. Lab. Clin. Med. 44:301-307.

18. Kinkel, L. L., Wilson, M., and Lindow, S. E. 1996. Utility of microcosm studies for predicting phylloplane bacterium population sizes in the field. Appl. Environ. Microbiol. 62:3413-3423.

19. Lawton, M., and MacNeil, B. 1986. Occurrence of race 1 of Pseudomonas syringae pv. tomato on field tomato in southwestern Ontario. Can. J. Plant Pathol. 8:85-88.

20. Lindemann, J., Arny, D. C., and Upper, C. D. 1984. Use of an apparent infection threshold population of Pseudomonas syringae to predict incidence and severity of brown spot of bean. Phytopathology 74:1334-1339.

21. Mitchell, R. 1982. Coronatine production by some phytopathogenic pseudomonads Physiol. Plant Pathol. 20:83-89.

22. Sambrook, J., Fritsch, E. F., and Maniatis, T. 
1989. Molecular Cloning: A Laboratory Manual. 2nd ed. Cold Spring Harbor Laboratory, Cold Spring Harbor, NY.

23. Schneider, R. W., and Grogan, R. G. 1977. Bacterial speck of tomato: Sources of inoculum and establishment of a resident population. Phytopathology 67:388-394.
24. Schneider, R. W., and Grogan, R. G. 1977. Tomato leaf trichomes, a habitat for resident populations of Pseudomonas tomato. Phytopathology 67:898-902.

25. Smitley, D. R., and McCarter, S. M. 1982. Spread of Pseudomonas syringae pv. tomato and role of epiphytic populations and envi- ronmental conditions in disease development. Plant Dis. 66:713-717.

26. Vidaver, A. K. 1967. Synthetic and complex media for the rapid detection of fluorescence of phytopathogenic pseudomonads: Effect of the carbon source. Appl. Microbiol. 15:15231524. 